\title{
Functionally Distinct Groups of Interneurons Identified During Rhythmic Carbachol Oscillations in Hippocampus In Vitro
}

\author{
Lori L. McMahon, John H. Williams, and Julie A. Kauer \\ Department of Neurobiology, Duke University Medical Center, Durham, North Carolina 27710
}

During distinct behavioral states, the hippocampus exhibits characteristic rhythmic electrical activity. Evidence in vivo suggests that both principal pyramidal cells and GABAergic interneurons participate in generating oscillations. We found that during rhythmic oscillations in area CA3, functionally distinct classes of interneurons could be identified, although all recorded interneurons had similar dendritic and axonal arbors. One group of interneurons was powerfully excited by CA3 pyramidal cells, whereas two other interneuron groups were relatively unaffected by pyramidal cell firing. One of these

The hippocampus exhibits characteristic oscillations in vivo correlated with specific behavioral states (Buzsaki et al., 1983; Bland, 1990; Buzsaki and Chrobak, 1995) and is also susceptible to rhythmic firing during temporal lobe epileptic seizures (Traub and Miles, 1991; Mody and Staley, 1994; Traub and Jefferys, 1994; Traub et al., 1996a). Although inhibitory interneurons constitute a small percentage of the neurons in hippocampus, their extensive axon arbors form GABAergic synapses on hundreds of local pyramidal cells (Buhl et al., 1994; Miles et al., 1996) (for review, see Freund and Buzsaki, 1996). As a consequence, interneurons influence the excitability of large groups of pyramidal cells and can therefore synchronize their electrical activity (Cobb et al., 1995; Whittington et al., 1995; Traub et al., 1996b; Toth et al., 1997). Control of interneuron excitability provides a direct route through which the output of the entire hippocampus can be altered. Therefore, understanding the control of interneuron excitability is fundamental to understanding patterns of electrical activity in the hippocampus.

Hippocampal interneurons are excited by numerous neurotransmitters including glutamate, serotonin, acetylcholine, and norepinephrine (Lacaille and Schwartzkroin, 1988; Sah et al., 1990; McBain and Dingledine, 1993; Bergles et al., 1996; Freund and Buzsaki, 1996; Jones and Yakel, 1997; McMahon and Kauer, 1997a; McQuiston and Madison, 1997; Frazier et al., 1998). In slices, electrical stimulation of the neuropil reveals synaptic responses in interneurons (Lacaille and Schwartzkroin, 1988; Sah et al., 1990; Maccaferri and McBain, 1995; McMahon and Kauer,

Received Dec. 4, 1997; revised May 11, 1998; accepted May 12, 1998.

Supported by National Institute of Neurological Diseases and Stroke Grant 30500 and Epilepsy Foundation of America Award to J.A.K. and National Research Service Award NS09734 to L.L.M. We thank Drs. Susan Jones, Lawrence Katz, and Richard Mooney for helpful comments on this manuscript, Dr. Lawrence Katz for use of camera lucida microscope, Scott Douglas and Andrew Pittman for histology, and Scott Greenberg for camera lucida drawings.

Correspondence should be addressed to: Julie Kauer, Department of Neurobiology, Box 3209, Duke University Medical Center, Durham, NC 27710.

Dr. Williams' present address: The Wellcome Trust, Neurosciences, 183 Euston Road, London NW1 2BE England.

Copyright (C) 1998 Society for Neuroscience $\quad 0270-6474 / 98 / 185640-12 \$ 05.00 / 0$ groups of interneurons was potently inhibited by other local interneurons during the pyramidal cell bursts. Our findings emphasize that morphologically similar cells are wired together very differently within the local circuit. The classes of hippocampal interneurons we have tentatively defined may be used during distinct behavioral states to switch the local network from one oscillatory state to another.

Key words: hippocampus; carbachol; oscillations; interneurons; GABAergic; epileptiform 1997b). However, the levels of spontaneous synaptic activity normally present in vivo are significantly reduced in vitro, and electrical activation of a heterogeneous population of afferents by a stimulating electrode does not mimic natural activation of the local circuit. In light of these difficulties, we examined the activity of interneurons in vitro during rhythmic activity generated intrinsically by local pyramidal cells.

The cholinergic agonist carbachol triggers synchronous rhythmic oscillations of the membrane potential in pyramidal neurons in the CA3 and CA1 regions (Konopacki et al., 1987; MacVicar and Tse, 1989; Traub et al., 1992; Huerta and Lisman, 1993, 1995, 1996; Williams and Kauer, 1997). We have recorded directly from interneurons in area CA3 during these carbachol oscillations. Several studies have suggested that classes of interneurons may be activated by distinct sets of afferents and are therefore likely to participate differently during activity in the local circuit (Sloviter and Nilaver, 1987; Freund and Antal, 1988; Freund et al., 1990). In support of this idea, we found interneurons with similar morphological features but distinct patterns of synaptic activity during carbachol oscillations.

\section{MATERIALS AND METHODS}

\section{Recordings and analysis}

Hippocampal slice preparation. All experiments were performed in strict accordance with a protocol approved by the Duke University Medical Center Institutional Animal Care and Use Committee. Slices were prepared from male Sprague Dawley rats aged 17-23 d as previously described (McMahon and Kauer, 1997a). Using a vibratome, coronal slices $(400 \mu \mathrm{m})$ were cut from the middle third of the hippocampus into ice-cold artificial CSF (in mM: $\mathrm{NaCl}, 119 ; \mathrm{NaHCO}_{3}, 26 ; \mathrm{KCl}, 2.5$; $\mathrm{NaH}_{2} \mathrm{PO}_{4}, 1.0 ; \mathrm{CaCl}_{2}, 2.5 ; \mathrm{MgCl}_{2}, 1.3$; and D-glucose, 11) saturated with $95 \% \mathrm{O}_{2}$ and $5 \% \mathrm{CO}_{2}$. Slices were held after cutting for 1-5 hr in an interface chamber at room temperature and then transferred to a recording chamber in which the slice was held submerged between two nets. The bath temperature was maintained between $29-31^{\circ} \mathrm{C}$.

Extracellular recording. Field potentials were recorded from area CA3b because we previously determined that carbachol oscillations are largest in this area (Williams and Kauer, 1997). Glass microelectrodes filled with $2 \mathrm{M} \mathrm{NaCl}$ were used to record in stratum radiatum as previously described (Williams and Kauer, 1997). Field potentials were recorded using 


\section{CA3 pyramidal cells}

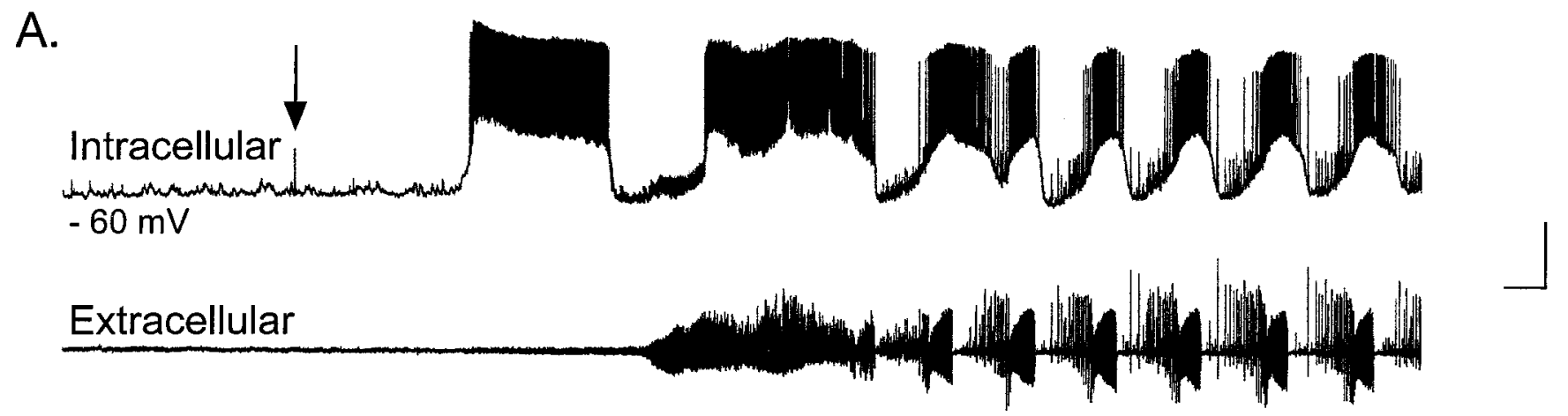

B.

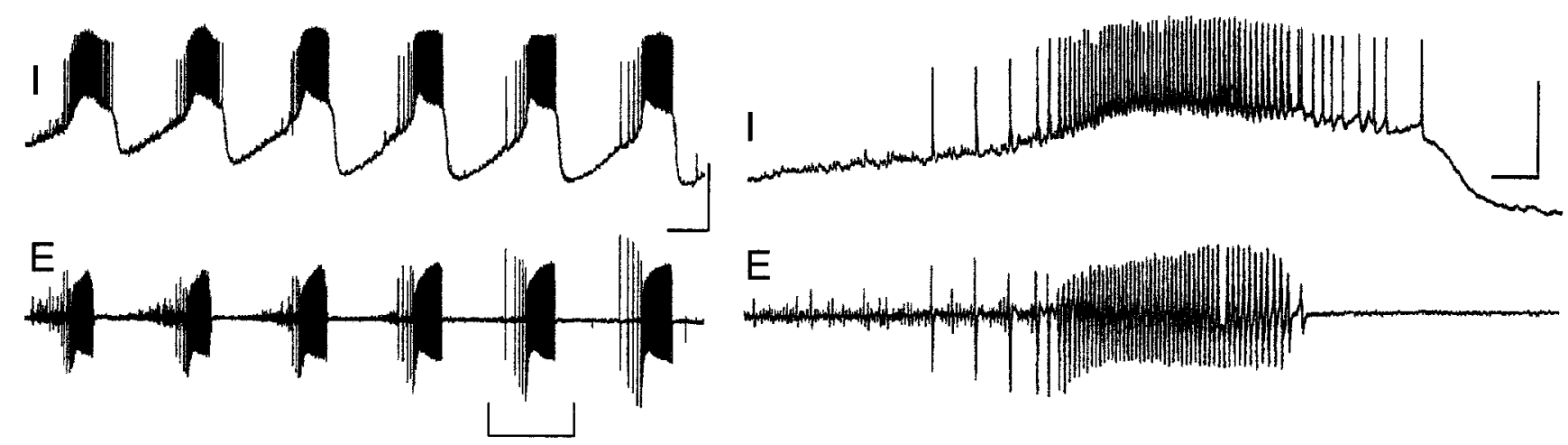

Figure 1. Carbachol induces depolarization and synchronous oscillations in CA3 pyramidal cells. $A$, Simultaneous whole-cell current-clamp recording from a CA3 pyramidal cell (top trace, intracellular) and extracellular dendritic field potential recording in stratum radiatum of CA3 (bottom trace, extracellular). Bath perfusion of $50 \mu \mathrm{M}$ carbachol (arrow) induces an abrupt $25 \mathrm{mV}$ depolarization of the pyramidal cell from its resting membrane potential $(-60 \mathrm{mV})$ beyond spike threshold. After 2-3 min in the continued presence of carbachol, an increase in noise is evident in the extracellular recording, as multiple pyramidal cells become synchronously active. $B$, Within minutes of carbachol application, groups of pyramidal cells become "entrained" to fire together in a rhythmic oscillatory pattern observable in both the cell (I, top) and the population (E, bottom). Traces on the right show a single burst on an expanded time scale. Calibration: $A, B$, left, $25 \mathrm{mV}$ intracellular, $0.2 \mathrm{mV}$ extracellular, $20 \mathrm{sec} ; B$, right, $800 \mathrm{msec}$.

an Axoclamp 2A amplifier and filtered at $25-30 \mathrm{~Hz}$ for on-line display and were also collected on video tape. Data shown for extracellular oscillations are AC-coupled for clarity.

Interneuron recordings. Tight-seal whole-cell recordings were obtained from interneurons with cell bodies located in stratum (st.) radiatum or st. oriens of area CA3 or from CA3 pyramidal cells, using techniques described previously (McMahon and Kauer, 1997b). All interneurons and pyramidal cells had cell bodies outside the hilar region (or CA3c) defined by an imaginary line drawn between the two blades of the dentate granule cells; many of the interneuron cell bodies were in the region of CA3 closest to the hilus, CA3b in the classification of Lorente de No (1934). Patch electrodes had resistances of 2-5 M $\Omega$ when filled with (in mM): potassium gluconate, 100; EGTA, 0.6; Na-GTP, 0.3; Na-ATP, 2; $\mathrm{MgCl}_{2}$, 5; HEPES, 40; and biocytin, $0.4 \%$. Recordings were made using an Axoclamp 2A amplifier, and cells were recorded at their resting potential in bridge mode except as noted. Only interneurons that had overshooting action potentials were accepted for study. Input resistance ranged from 200 to $700 \mathrm{M} \Omega$, and series resistance ranged from 10 to $30 \mathrm{M} \Omega$. Input resistance and series resistance were carefully monitored on-line, and experiments were discarded if changes $>10 \%$ were seen. Under our recording conditions, $\mathrm{GABA}_{\mathrm{A}}$ receptor-mediated IPSPs reversed polarity at approximately $-60 \mathrm{mV}$. Records were filtered at $1-2$ $\mathrm{kHz}$ and recorded on chart paper and video tape.

Carbachol-induced oscillations. Interneuron recordings were used only if bath-applied carbachol (Sigma, St. Louis, MO; $50 \mu \mathrm{M}$ ) elicited regular oscillations, defined as $>$ five consecutive regularly spaced trains of burst activity in the extracellular field potential records (Williams and Kauer, 1997). Picrotoxin (Sigma; $100 \mu \mathrm{M}$ ) was bathapplied in some experiments.
Biocytin processing. Slices were fixed immediately after use in $4 \%$ paraformaldehyde and resectioned at $75 \mu \mathrm{m}$. The sections were reacted as described with avidin-horseradish peroxidase (McBain et al., 1994), cleared in xylene, and coverslipped. Camera lucida reconstructions were made using a $40 \times$ oil immersion objective.

\section{RESULTS}

\section{Carbachol-induced oscillations in CA3 pyramidal cells}

Bath application of carbachol $(50 \mu \mathrm{M})$ to hippocampal slices elicited repetitive bursts of rhythmic activity ("carbachol oscillations") recorded both extracellularly and intracellularly from CA3 pyramidal neurons (Fig. 1). Initially, carbachol induced a 5-30 $\mathrm{mV}$ depolarization of individual CA3 pyramidal neurons beyond spike threshold (mean depolarization $\pm \mathrm{SEM}, 15 \pm 3$ $\mathrm{mV}$; resting membrane potential (RMP), $61 \pm 1 \mathrm{mV} ; n=10$ ), so that the cells fired action potentials at high frequency. Within minutes of the initial depolarization, activity in groups of pyramidal cells became synchronous, producing bursts of field potentials apparent in extracellular recordings (Fig. $1 \mathrm{~A}$, bottom trace). Once the population of pyramidal cells was firing in concert, carbachol oscillations occurred at regular intervals (Fig. 1B). Low-amplitude signals were occasionally observed in the extracellular record leading up to a burst; we speculate that these are 


\section{Class I interneuron}

A1. $-59 \mathrm{mV}$
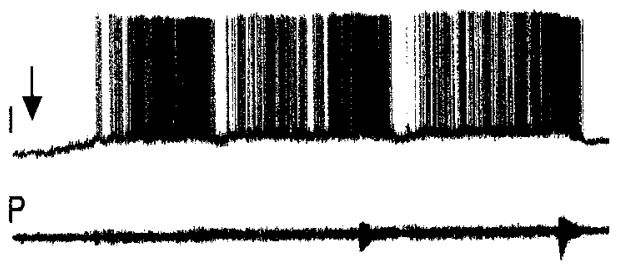

B1.

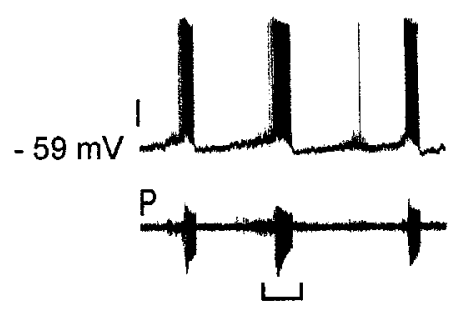

c1.

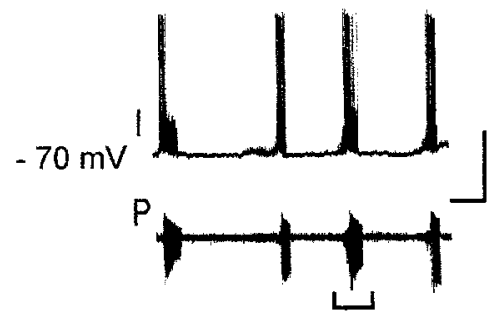

B2.

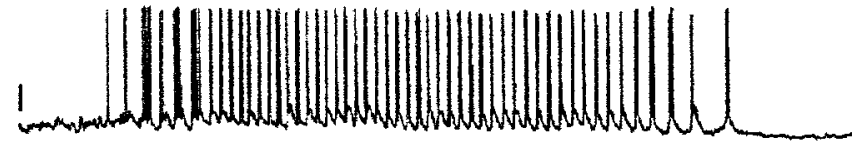

$P$
C2.

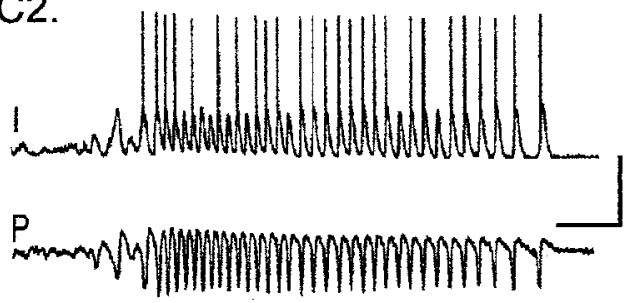

Figure 2. Class I interneurons are depolarized during oscillations in pyramidal cells. A1, Simultaneous whole-cell current-clamp recording of a visually identified interneuron in stratum radiatum of CA3 $(I)$ and extracellular pyramidal cell dendritic field potential recording in stratum radiatum $(P)$. Bath perfusion of $50 \mu \mathrm{M}$ carbachol (arrow) induces an $8 \mathrm{mV}$ depolarization of the interneuron from the resting membrane potential ( $-59 \mathrm{mV})$ to action potential threshold. Within 3-4 min in the continued presence of carbachol, oscillatory events begin to emerge in the pyramidal cells (bottom trace). B1, Synchronous rhythmic bursts appear in the interneuron and pyramidal cells (6 min in carbachol). In the interim between oscillatory events, the interneuron returns to the resting membrane potential. B2, Expanded time scale of a single burst (bracket) reveals that each event in the pyramidal cell population is precisely correlated with a burst of two or three action potentials in the interneuron. $C 1, C 2$, When the cell is hyperpolarized to $-70 \mathrm{mV}$ with constant current injection, some of the population events are now paralleled by subthreshold EPSPs recorded from the interneuron. Calibration: $A 1, B 1, C 1,40 \mathrm{mV}$ intracellular, $0.1 \mathrm{mV}$ extracellular, $20 \mathrm{sec} ; B 2, C 2,800 \mathrm{msec}$.

caused by firing in small groups of pyramidal cells before the population is entirely recruited.

Together with previous work (MacVicar and Tse, 1989; Traub et al., 1992; Williams and Kauer, 1997), these results suggest that carbachol depolarizes CA3 pyramidal cells directly, and excitatory synaptic connections among these cells then allow the population to fire in a gradually more and more coordinated manner, eventually producing regular bursts.

\section{Carbachol-induced oscillations in GABAergic interneurons}

We simultaneously recorded from visually identified interneurons in either stratum radiatum or stratum oriens of area CA3 and extracellularly from CA3 pyramidal cell dendrites in the same stratum. We distinguished three interneuron classes based on differing physiological responses during carbachol oscillations in pyramidal neurons. One interneuron class was depolarized to threshold during the bursts, and several of these cells exhibited a characteristic "run-up" of activity preceding the pyramidal cell burst. A second, rarely encountered interneuron class was hyperpolarized during each population burst; the hyperpolarization was bicuculline-sensitive, suggesting a powerful GABAergic input to these interneurons. A third cell class was remarkably unaffected by the bursting activity in nearby pyramidal cells, indicating that this cell type was not synaptically driven by CA3 pyramidal cells or local GABAergic interneurons active during the oscillations.

Class I: st. radiatum interneurons that are depolarized during the carbachol oscillations

Twenty-seven of 42 CA3 st. radiatum interneurons were excited during carbachol-induced bursts in pyramidal cells (class I). As carbachol entered the bath and before the onset of pyramidal cell bursting, interneurons in this class depolarized by $2-30 \mathrm{mV}(10 \pm$ $1 \mathrm{mV} ; n=24)$ from the resting membrane potential $(55 \pm 1 \mathrm{mV}$; $n=23$ ) to threshold and fired action potentials at high frequency (Fig. $2 A ; n=19$ of $27 ; 8$ of 27 depolarized but did not reach threshold). The initial depolarization of the interneuron membrane also occurred in the same cells after synaptic transmission was blocked by $1 \mu \mathrm{M}$ tetrodotoxin (TTX), indicating a direct action of carbachol at postsynaptic cholinergic receptors (data not shown) (depolarization in TTX, $100 \%$ of that without TTX, $n=$ $3 ; 50 \%$ of that without TTX, $n=1$ ). These data indicate that class I cells express cholinergic receptors that strongly depolarize the interneuron directly. In TTX, carbachol did not induce oscillatory activity, emphasizing that carbachol oscillations are synaptically driven.

Once the bursting period began in pyramidal cells, class I interneurons were excited synchronously with the pyramidal cells, often with bursts of three to five spikes riding on an EPSP. The membrane potential often remained depolarized in the continued presence of carbachol. Action potentials were reduced in amplitude compared with those before carbachol and often did not overshoot $0 \mathrm{mV}$ (cf. Bianchi and Wong, 1994; Lukatch and MacIver, 1997); this is probably a result of the documented blockade of $\mathrm{Na}^{+}$channels after treatment with carbachol (Cantrell et al., 1996). At the end of each pyramidal cell burst, the interneuron hyperpolarized, entering a quiet period before spiking resumed. Hyperpolarization to $-70 \mathrm{mV}$ revealed underlying subthreshold EPSPs (Fig. 2, compare $B, C$ ). In the period between pyramidal cell bursts, most class I interneurons (14 of 27) fired single action potentials followed by modest afterhyperpolarizations (data not shown). 
In a subset of interneurons in this class ( $n=7$ of 27$)$, the membrane potential exhibited a "ramp" depolarization preceding the oscillation in the pyramidal cell population (Fig. 3). Bursts of action potentials occurred at high frequency $(>30 \mathrm{~Hz})$, increasing as the cells became more depolarized, and the cells continued firing throughout the field oscillation. Each action potential during the ramp depolarization was followed by a prominent afterhyperpolarization. In five of seven interneurons exhibiting the ramp depolarization, the interneurons fired bursts of action potentials riding on characteristically broad waves of depolarization that may be EPSPs or plateau potentials (Fig. 3B2).

Early during carbachol exposure, each depolarizing burst in the interneuron did not have a corresponding oscillation in the population (Fig. 3A). During early uncorrelated bursts of action potentials in one interneuron, inhibition of the pyramidal cells was clearly observed, as indicated by the decreased noise in the extracellular record (Fig. 3A2, arrows). The silencing of the pyramidal cell population is presumably attributable to GABAergic inhibition of multiple local pyramidal cells during firing in the recorded interneuron. At the onset of carbachol oscillations, these independent oscillatory events in the interneuron may help to synchronize the firing of local pyramidal cells. Once the population of pyramidal cells established regular rhythmic oscillations, each burst in the interneuron became tightly correlated with a population oscillation in the pyramidal cells (Fig. $3 B$ ). When the interneuron was hyperpolarized to $-70 \mathrm{mV}$, the ramp depolarization was absent, and multiple excitatory synaptic events were apparent (Fig. 3B, right panels).

Class I interneurons are robustly excited during the firing of CA3 pyramidal cells. Although class I interneurons exhibit both electrically evoked and spontaneous IPSPs before and during carbachol treatment (data not shown), during carbachol oscillations these interneurons are not prevented from firing by other inhibitory interneurons. Class I interneurons also contribute potent inhibition to groups of pyramidal cells, most clearly seen when the pyramidal cells have not begun to fire regularly (Fig. $3 A 2)$.

\section{Class II: interneurons that are hyperpolarized during the carbachol oscillations}

Interneurons in this class were rarely encountered $(n=3$ of 42) but exhibit such distinct electrical activity during carbachol oscillations that we have categorized them into a single class for convenience. Carbachol application elicited a modest membrane depolarization ( $0-5 \mathrm{mV}$ ) before the onset of bursting (data not shown). During the burst period in pyramidal cells, class II interneurons received IPSPs that increased in size when the cell was held at a depolarized potential (Fig. 4). When class II interneurons were held hyperpolarized, the IPSPs reversed polarity at the $\mathrm{Cl}^{-}$equilibrium potential, suggesting that they are $\mathrm{GABA}_{\mathrm{A}}$ receptor-mediated (Fig. $4 A$, right panels).

The $\mathrm{GABA}_{\mathrm{A}}$ receptor antagonist picrotoxin $(100 \mu \mathrm{M})$ attenuated the hyperpolarization and IPSPs during the carbachol oscillation $(n=2)$. In the presence of picrotoxin, EPSPs were unmasked that were correlated with the field events during the oscillation (Fig. 4B, left panels). When the interneuron was hyperpolarized in the presence of picrotoxin, EPSPs during the burst were increased in amplitude (Fig. 4B, right panels). We hypothesize that interneurons in this class, although receiving weak excitatory innervation from local pyramidal cells, also receive potent inhibitory innervation, perhaps from some of the class I interneurons that are excited and release GABA during the pyramidal cell oscillation.

\section{Class III: interneurons whose activity is not correlated with the oscillation in pyramidal cells}

Eleven of 42 interneurons responded differently during carbachol oscillations than interneurons in either class I or II: these interneurons appeared to be synaptically isolated from the pyramidal cells and are thus referred to as class III. Carbachol depolarized 5 of 11 interneurons in this class to threshold, triggering action potentials at frequencies from 3 to $15 \mathrm{~Hz}$ (Fig. $5 A$ ). These interneurons continued to fire action potentials at the same frequency during burst activity in pyramidal cells, without altering their activity (Fig. $5 A$, right panel, $B$ ). When the membrane potential was hyperpolarized below action potential threshold $(n=4)$, small EPSPs were just visible above baseline noise in two of these interneurons during the pyramidal cell burst; the other two interneurons were silent during the burst (data not shown). The remaining class III interneurons (6 of 11) did not reach spike threshold in carbachol. Three interneurons were silent during the oscillation in pyramidal cells, and three had EPSPs just visible above the basal synaptic noise. Taken together, these data suggest that neither local pyramidal cells nor local interneurons significantly influence the excitability of class III interneurons during carbachol oscillations.

Sparse synaptic input to class III interneurons could be an artifact of slicing. Although it is not possible to rule this out entirely, it is unlikely for several reasons. The interneuron dendrites observed in biocytin-filled cells were not shorter or closer to the sliced surface than for interneurons of the other classes, suggesting we have not simply removed the synaptic surface. Moreover, electrical stimulation delivered in st. radiatum always elicited both EPSPs and picrotoxin-sensitive IPSPs in class III neurons (data not shown), and carbachol elicited an increase in spontaneous EPSPs and IPSPs in these cells not correlated with burst activity. Thus, it is very unlikely that interneurons with normal length dendrites and functional excitatory and inhibitory synapses would be frequently encountered and yet entirely disconnected from other local neurons. Thus, these interneurons receive afferent inputs and are innervated by neurons excited by carbachol but are not innervated by excitatory and inhibitory neurons active during carbachol oscillations. We describe below that the majority of class III interneurons were found in one particular region of area CA3 (the CA2 region), whereas the majority of class I interneurons were found elsewhere. This may help to explain the physiological differences observed.

\section{St. oriens interneurons}

Nearly all of the interneurons from which we recorded with cell bodies in st. radiatum had axons primarily localized within st. radiatum (detailed in the next section). We also wanted to record responses from interneurons innervating st. pyramidale, so we recorded from an additional five interneurons with cell bodies in st. oriens, many of which innervate the pyramidal cell bodies (Freund and Buzsaki, 1996; Miles et al., 1996). Interneurons in st. oriens behaved much like class I interneurons in st. radiatum. Four of five neurons depolarized to action potential threshold in response to carbachol with EPSPs occurring in synchrony with pyramidal cell bursts (Fig. 6A,B). Therefore, we have considered these interneurons to fall within class I. In a recording from one st. oriens cell (data not shown) when the interneuron was firing, 


\section{Class I interneuron - ramp}

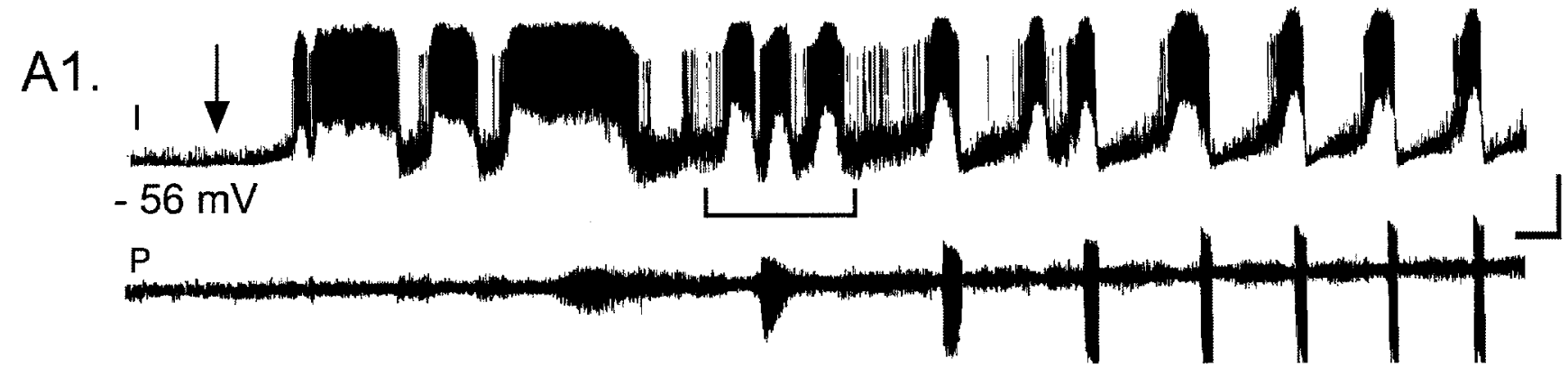

A2.
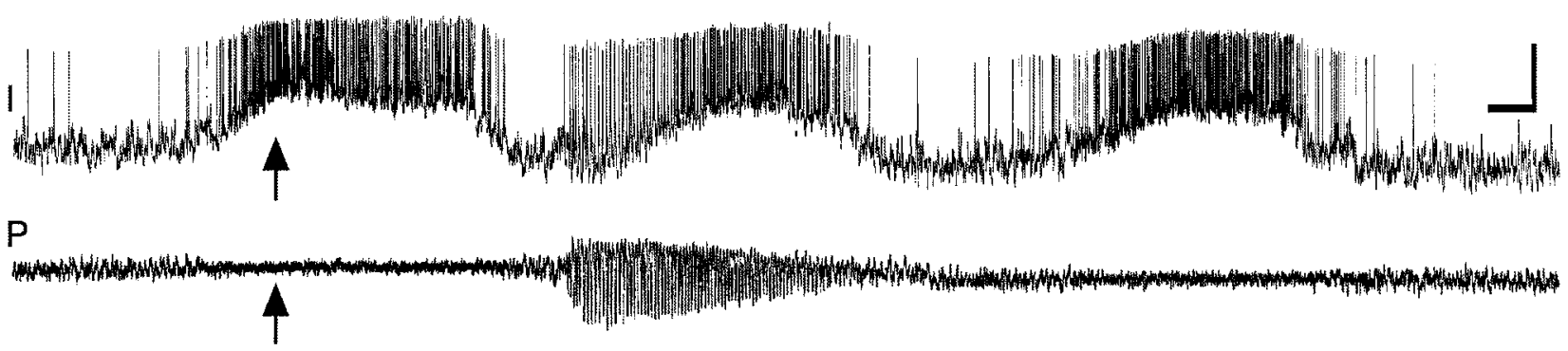

B1.

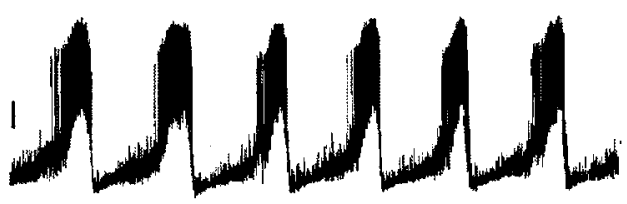

$-56 \mathrm{mV}$

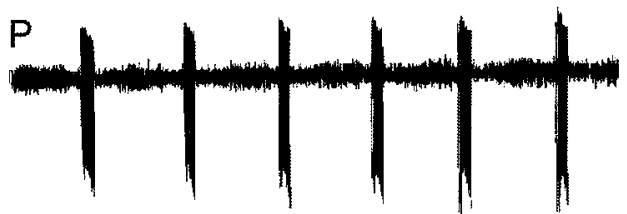

B2.

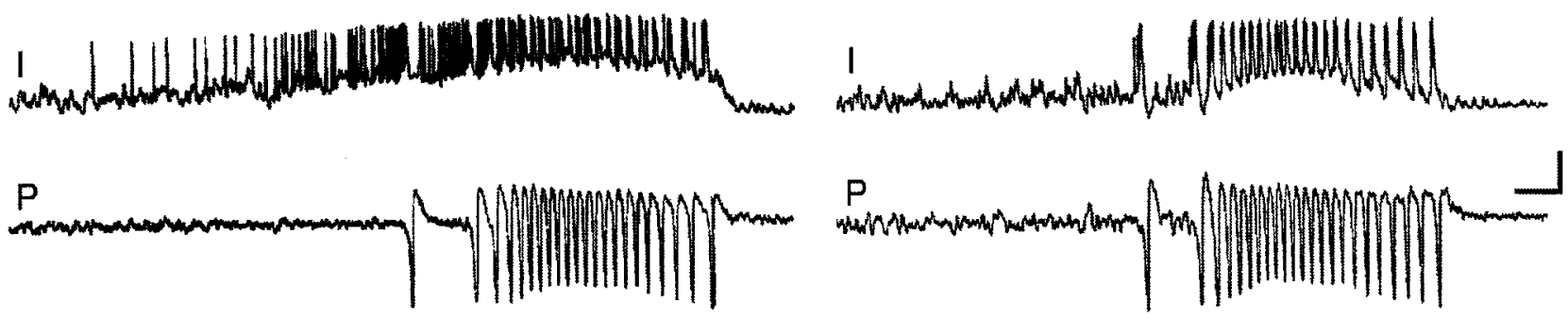

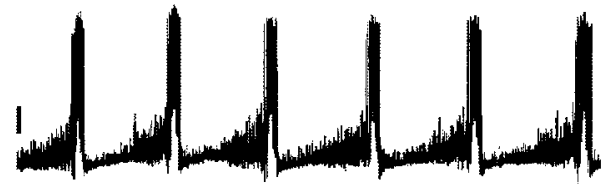

$-70 \mathrm{mV}$

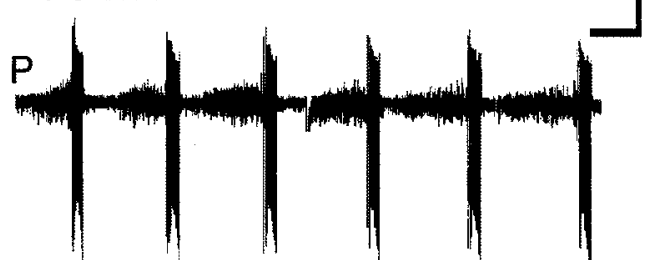

Figure 3. A subset of class I interneurons exhibit a characteristic ramp depolarization before the pyramidal cell burst. $A 1$, Simultaneous whole-cell recording from a stratum radiatum interneuron $(I)$ and extracellular pyramidal cell dendritic field potential recording $(P)$. Carbachol $(50 \mu \mathrm{M})$ perfusion (arrow) elicits a $25 \mathrm{mV}$ depolarization of the interneuron from rest $(-56 \mathrm{mV})$. A2, Expanded time scale $($ A1, bracketed region) showing that during the initial bursts of action potentials in the interneuron, the pyramidal cell population is inhibited. Note the decrease in noise in the extracellular pyramidal cell recording during interneuron activity (arrows). B1, left panel, After $6 \mathrm{~min}$ in the continued presence of carbachol, firing in the interneuron is now entirely correlated with the pyramidal cell bursts. B2, left panel, Single burst on an expanded time scale shows that action potentials in the interneuron increase in frequency just before the pyramidal cell burst. B1, right panel, When the interneuron is hyperpolarized to $-70 \mathrm{mV}$ with constant current injection, the ramp depolarization is reduced in amplitude. B2, right panel, Ramp depolarization is absent when the interneuron is held at $-70 \mathrm{mV}$ (note expanded time scale). Calibration: $A 1, B 1,50 \mathrm{mV}$ intracellular, $0.1 \mathrm{mV}$ extracellular, $10 \mathrm{sec}$; $A 2,800 \mathrm{msec} ; B 2,400 \mathrm{msec}$. 


\section{Class II interneuron}

\section{carbachol}
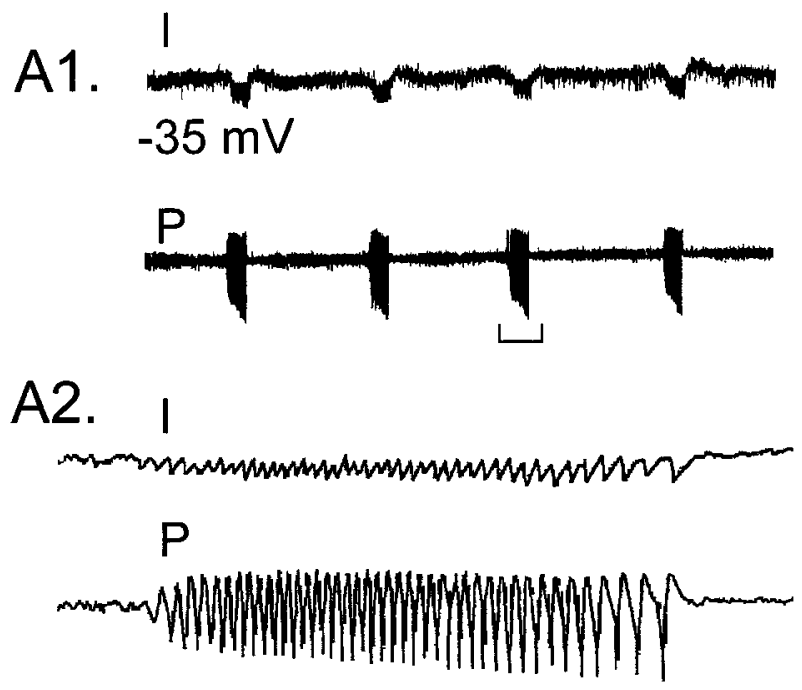

carbachol + picrotoxin

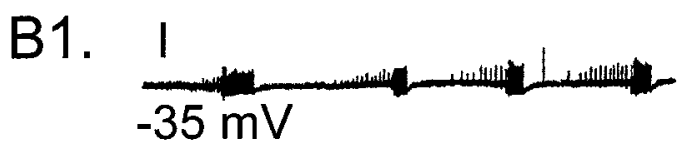

B2.
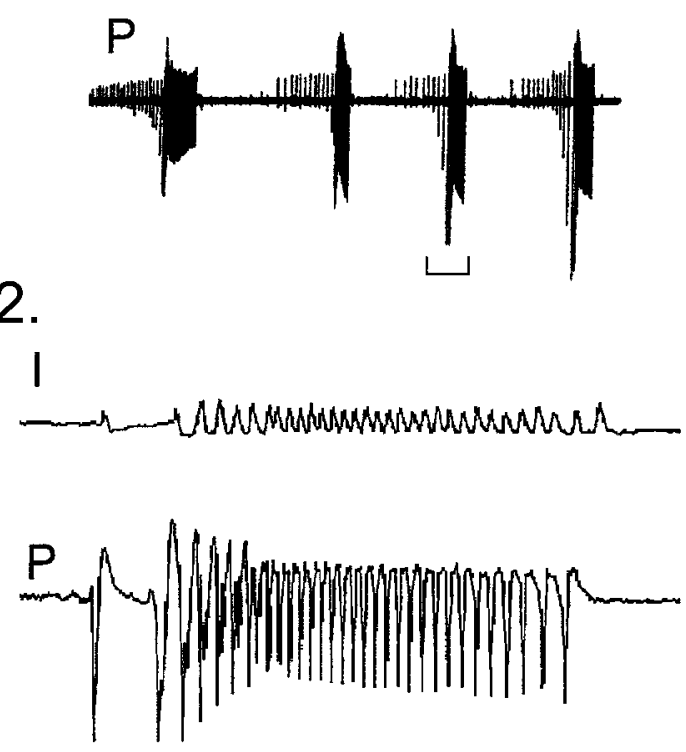
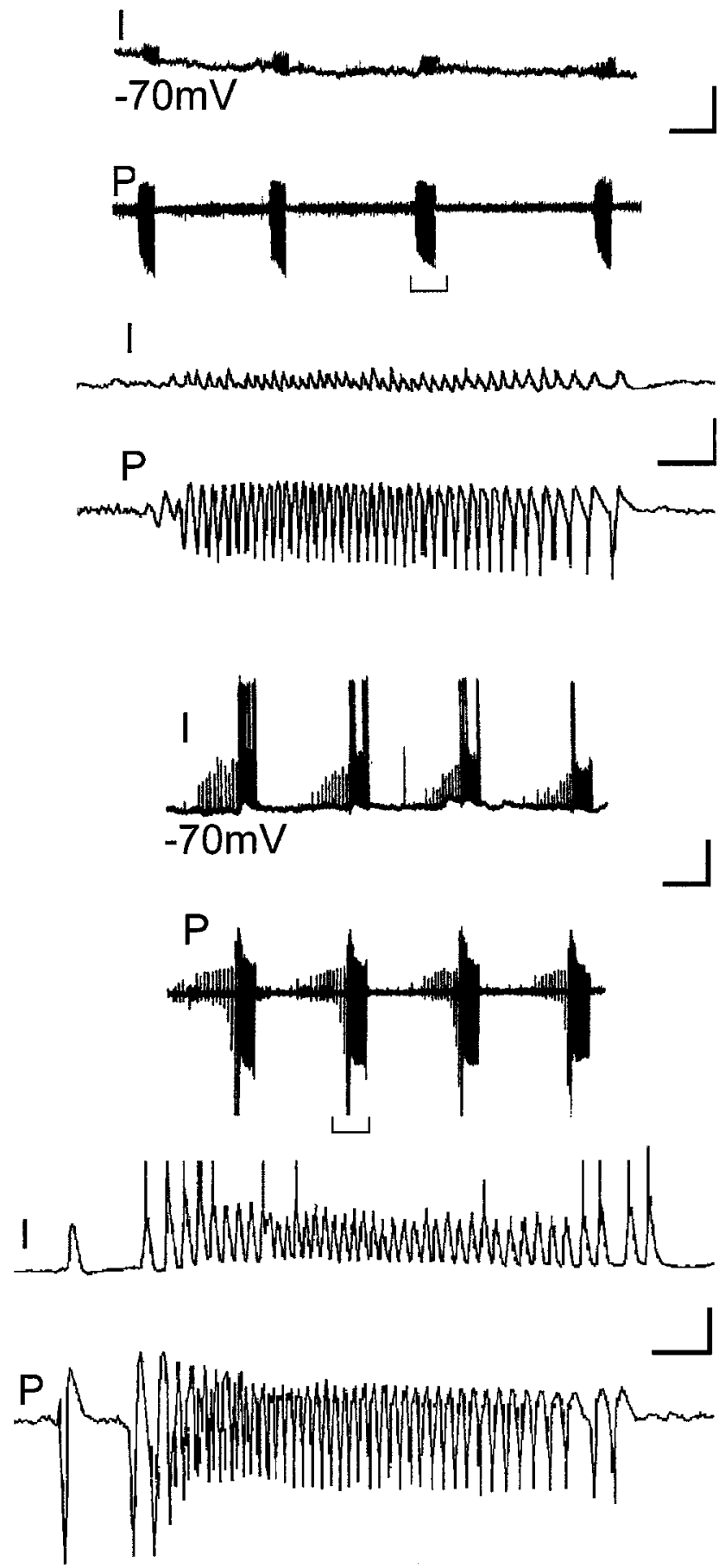

Figure 4. Class II interneurons are hyperpolarized during pyramidal cell bursts. A, left traces, Class II interneuron held at $-35 \mathrm{mV}$ hyperpolarizes during each pyramidal cell burst. A1, Bottom traces show a pyramidal cell burst (bracket) with interneuron IPSPs paralleled by each field event in the extracellular pyramidal cell recording. $A$, right traces, When the cell is held at $-70 \mathrm{mV}$, the burst-associated hyperpolarization in the interneuron is absent. A2, Expanded time scale of a burst (A1, bracketed region) shows that the IPSPs have reversed polarity. B, left traces, In the same experiment, addition of picrotoxin $(100 \mu \mathrm{M})$ to the perfusate blocks the burst-associated interneuron hyperpolarization observed at $-35 \mathrm{mV}$. B2, left, Expanded time scale unmasks EPSPs, which are temporally correlated with individual field events. $B$, right traces, When the interneuron is held at $-70 \mathrm{mV}$ in the continued presence of picrotoxin, some EPSPs now reach threshold during the pyramidal cell burst. B2, Traces are displayed on an expanded time scale. Calibration: $A 1, B 1,16 \mathrm{mV}$ intracellular, $0.1 \mathrm{mV}$ extracellular, $12.5 \mathrm{sec} ; A 2, B 2,500 \mathrm{msec}$. 


\section{Class III interneuron}

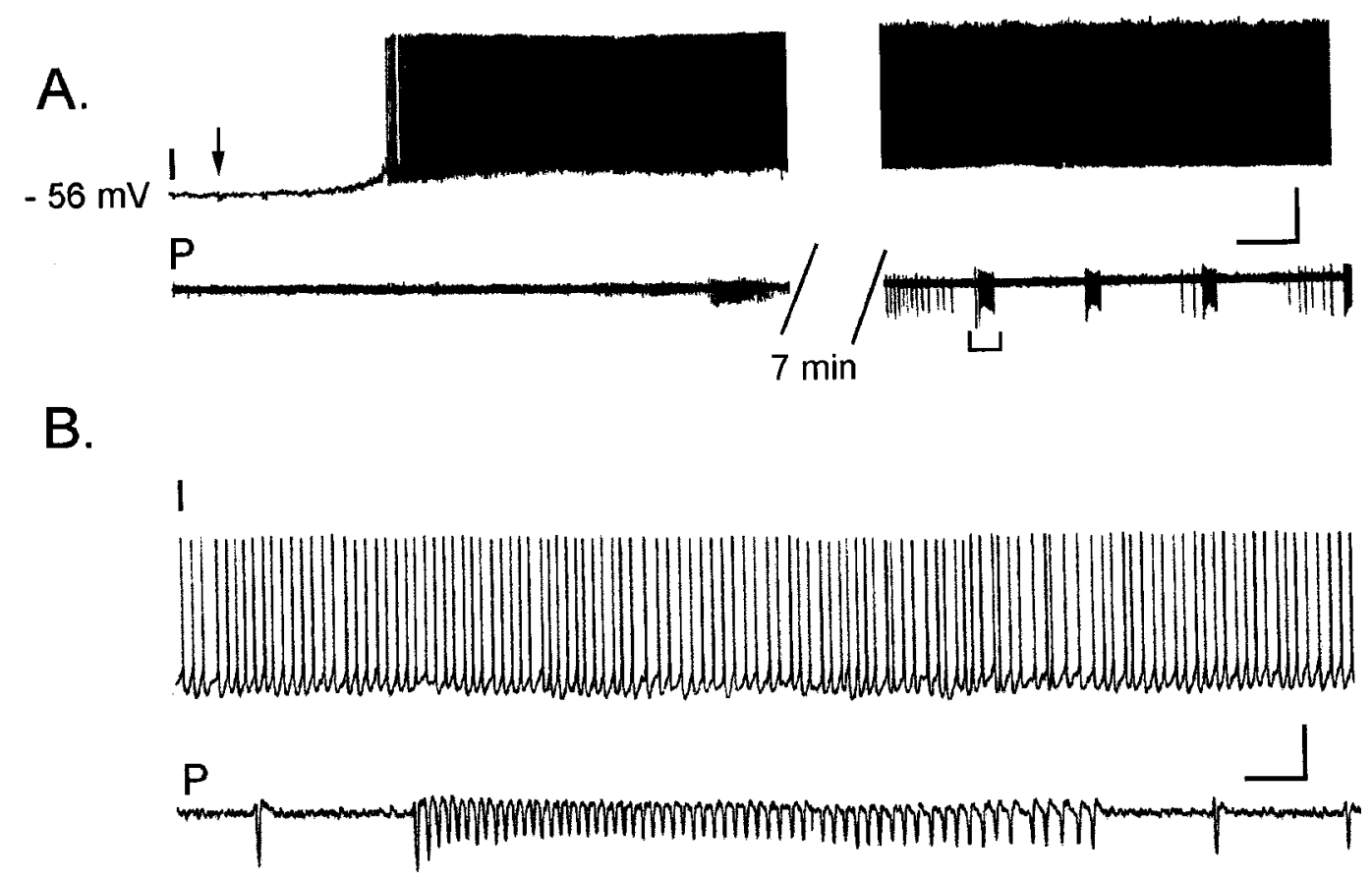

Figure 5. Class III interneurons have electrical activity uncorrelated with the pyramidal cell bursts. A, left traces, Bath application of $50 \mu \mathrm{M}$ carbachol (left panel, arrow) elicits a $10 \mathrm{mV}$ depolarization (RMP, $-56 \mathrm{mV}$ ) in which the cell fires action potentials at $\sim 8-10 \mathrm{~Hz}(I)$. A, right traces, As the oscillatory activity begins in the extracellular pyramidal cell recording $(P)$, the interneuron firing pattern remains unchanged (6-8 min in carbachol). $B$, On an expanded time scale $(A$, bracketed region $)$ the interneuron activity is unaffected by the burst in the pyramidal cells. Calibration: $A, 20 \mathrm{mV}$ intracellular, $0.1 \mathrm{mV}$ extracellular, $10 \mathrm{sec} ; B, 400 \mathrm{msec}$.

the pyramidal cell record grew noticeably quieter (as in Fig. $3 A 2$ for a st. radiatum interneuron).

\section{Out-of-phase interneuron}

Only 1 of 47 CA3 interneurons displayed rhythmic activity that was entirely out of phase with pyramidal cell oscillations. This interneuron was heavily innervated by other GABAergic neurons, as indicated by an unusually high frequency of spontaneous IPSPs compared with the other interneurons recorded in this study. Carbachol depolarized the neuron $\sim 4 \mathrm{mV}$ to threshold and, after several minutes in the continued presence of carbachol, the cell exhibited rhythmic depolarizations accompanied by broad action potentials. During the discharges in the interneuron, the field recording was silent. When the interneuron repolarized, increased noise was again observed in the population. The morphological features of this interneuron were not significantly different from other recorded interneurons (Fig. 7, bottom).

\section{Interneuron anatomy}

\section{St. radiatum interneurons}

We were interested in knowing whether the distinct physiologically defined interneuron classes we identified also exhibited distinct morphologies. Based on biocytin fills of each interneuron, however, we were most struck by the general similarity in dendritic and axonal arbors in interneurons in all classes. Twentyeight of 42 recorded st. radiatum interneurons could be identified from the biocytin fills. These interneurons had three or four primary dendrites whose branches were nearly always confined within st. radiatum and occasionally $(n=4)$ extended one branch into st. oriens (Fig. 7). Two interneurons extended a dendrite into the hilus and granule cell layer of the dentate gyrus. Spines were observed on the dendrites of 5 of 28 neurons.

Axons were recovered from 23 filled neurons. Axon arbors most often projected densely within st. radiatum (20 of 23), and some axon was recovered within the hilus/CA3c $(n=9)$, granule cell layer $(n=2)$, and molecular layer $(n=2)$ of the dentate gyrus. Two interneuron axons arborized almost exclusively within the CA3 pyramidal cell layer, resembling the axons of basket cells in the CA1 region (Buhl et al., 1994; McBain et al., 1994; Freund and Buzsaki, 1996; McMahon and Kauer, 1997a,b).

Of 17 biocytin-labeled class I st. radiatum interneurons, 13 had cell bodies located in CA3b, 2 in CA3a, and 2 in CA2. Of the interneurons located in CA3b, 11 cells innervated st. radiatum, 3 cells extended axon into st. lacunosum-moleculare, 3 cells had at least some axon within the pyramidal cell layer, and 1 preferentially ramified within st. pyramidale. One interneuron projected axon to the CA1 region and ramified on both sides of the hippocampal fissure. Of the two class I interneurons with somas located in CA3a, one innervated st. pyramidale in CA3b; the other innervated st. radiatum and st. lacunosum-moleculare. The axon of one interneuron located in CA2 ramified in st. radiatum within CA3a; axon from the second cell was not recovered. Physiologically, the two neurons that innervated st. pyramidale resembled other class I interneurons. Eight of nine interneurons that projected to the dentate gyrus had somas in CA3b and were defined physiologically as class I interneurons.

Class I cells exhibiting a ramp depolarization before the pyra- 


\section{Class I - s. oriens interneuron}

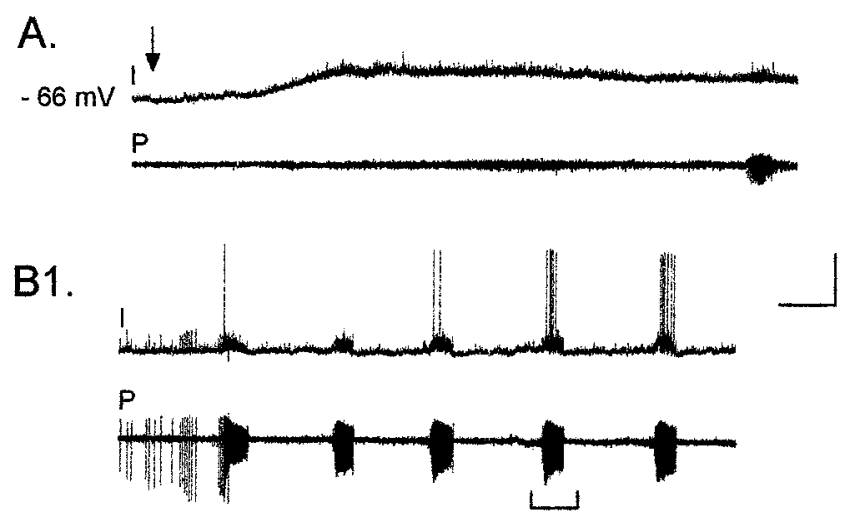

B2.

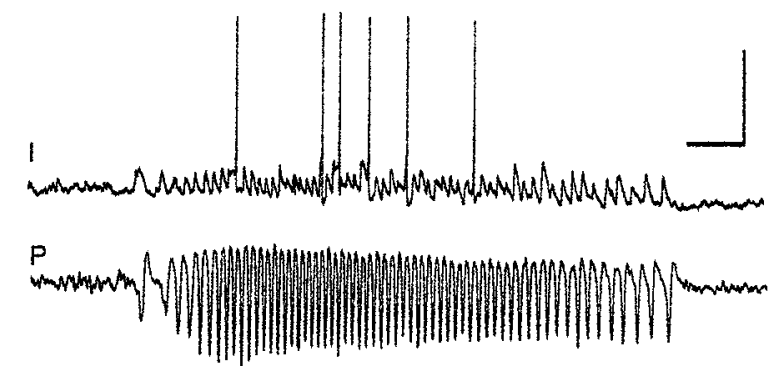

Figure 6. Oscillatory activity of CA3 stratum oriens interneurons is similar to class I stratum radiatum interneurons. $A$, Stratum oriens interneuron is depolarized $(\sim 10 \mathrm{mV}$; RMP,$-66 \mathrm{mV})$ during bath application of $50 \mu \mathrm{M}$ carbachol $(I)$. Bottom trace $(P)$ is the extracellular recording from pyramidal cell dendrites. B1, Pyramidal cell bursts are correlated with EPSPs in the interneuron. $B 2$, This is most clearly seen when a burst ( $A$, bracketed region) is displayed at an expanded time scale. Calibration: $A, B 1,25 \mathrm{mV}$ intracellular, $0.2 \mathrm{mV}$ extracellular, $20 \mathrm{sec} ; B 2,800 \mathrm{msec}$.

midal cell burst were not noticeably different in morphology from class I cells without the ramp (Fig. 7, top left and right panels). Although the class I (ramp) interneuron illustrated in Figure 7 (top right) appears more elongated in its dendritic tree, with its soma close to the st. lucidum-st. radiatum border, four other biocytin-filled cells in the same physiological class had cell bodies either in the middle of st. radiatum or at the st. radiatum-st. lacunosum-moleculare border. Thus, despite some apparent differences in the illustrated cells, we did not find convincing evidence of different gross morphologies between class I cells with and without the ramp (Fig. 7, top right). Differences were observed in the dendrites, however; small spines could clearly be observed on three of five class I cells exhibiting the ramp depolarization, whereas 10 other class I cells appeared spine-free. Recent evidence indicates that a subset of spiny interneurons with cell bodies and dendrites confined to st. lucidum may be excitatory, releasing glutamate instead of GABA (Soriano and Frotscher, 1993; Spruston et al., 1997). Possibly some of the class I ramp interneurons may fall into this unusual class.

All three class II interneurons filled well with biocytin, and all had dendrites in st. radiatum and st. lacunosum-moleculare, with axons also confined to these layers (Fig. 7, middle left). One of the three had some small spines, whereas the other two were spinefree. These neurons appeared very similar to most class I interneurons.

Seven of 11 class III cells were filled well with biocytin. The morphological features of class III interneurons were also similar to interneurons in the other classes, with the exception of cell body location. The somas of six of seven interneurons in this class were located in CA2, the region closest to CA1; the soma of the remaining neuron was in CA3a. Although biocytin fills were poor for the other four class III interneurons, at least two of these also had cell bodies in the CA2-CA3 region. The dendrites projected within st. radiatum and st. lacunosum-moleculare with a branch from one cell extending into st. pyramidale (Fig. 7, bottom left). One interneuron had long, thin, spine-like processes extending from swellings along the length of the dendrite. Axon was recovered from five class III interneurons. The axons of all five cells ramified within st. radiatum and st. lacunosum-moleculare of CA2 and CA3a. Three of five neurons projected axon well into CA3b, and one cell extended axon into CA1. Thus, our data indicate that most class I and II interneurons were located close to CA3b, whereas most class III interneurons were located at the other end of CA3 closest to area CA1. This difference in cell location may be responsible for the physiological differences we report.

\section{St. oriens interneurons}

Interneurons with cell bodies in st. oriens were physiologically characterized as class I interneurons. The dendrites of three of five biocytin-filled st. oriens cells were confined to that layer, whereas branches of dendrites from two st. oriens interneurons projected into st. radiatum as well. The dendrites of one cell had noticeable spines. Two of five st. oriens interneurons had axons tightly confined near st. pyramidale (Fig. 7, middle right); two other cells innervated st. radiatum; one had no recovered axon.

\section{DISCUSSION}

This is the first attempt to classify interneurons in vitro during rhythmic electrical activity. We used carbachol to trigger oscillatory activity in area CA3 to assess synaptic connections as they naturally occur during intrinsic activity in the network. Interneuron responses were grouped based on their patterns of excitation and inhibition during carbachol oscillations. A simple scheme of alternating inhibition and excitation, as observed during spindle waves in the thalamus, cannot account for carbachol oscillations (Bal et al., 1995). Carbachol oscillations are most likely driven primarily by CA3 pyramidal cells, which excite one another and class I interneurons through multiple collaterals. Class II interneurons receive more powerful inhibitory connections than excitatory connections; some of the class I interneurons with axons in st. radiatum could provide this inhibition. Class III interneurons probably receive little input from rhythmically active CA3b pyramidal cells or class I interneurons and might instead act preferentially to disseminate information received from other brain regions. The interneuron classes we have identified in vitro could play specific and distinct roles during a variety of network-driven in vivo oscillations.

\section{The role of interneurons in carbachol burst generation}

$\mathrm{GABA}_{\mathrm{A}}$ receptors are necessary for maintaining the repetitive structure of carbachol oscillations (Williams and Kauer, 1997); $\mathrm{GABA}_{\mathrm{B}}$ receptor blockade has no effect (MacVicar and Tse,

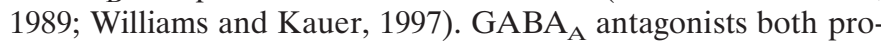
long the burst and produce prolonged, irregular interburst intervals (Williams and Kauer, 1997), most likely by blocking inhibition delivered by the three interneuron classes we have identified. A subset of class I (ramp) interneurons fires before the pyramidal cell burst and may contribute to burst onset by inhibiting multiple 

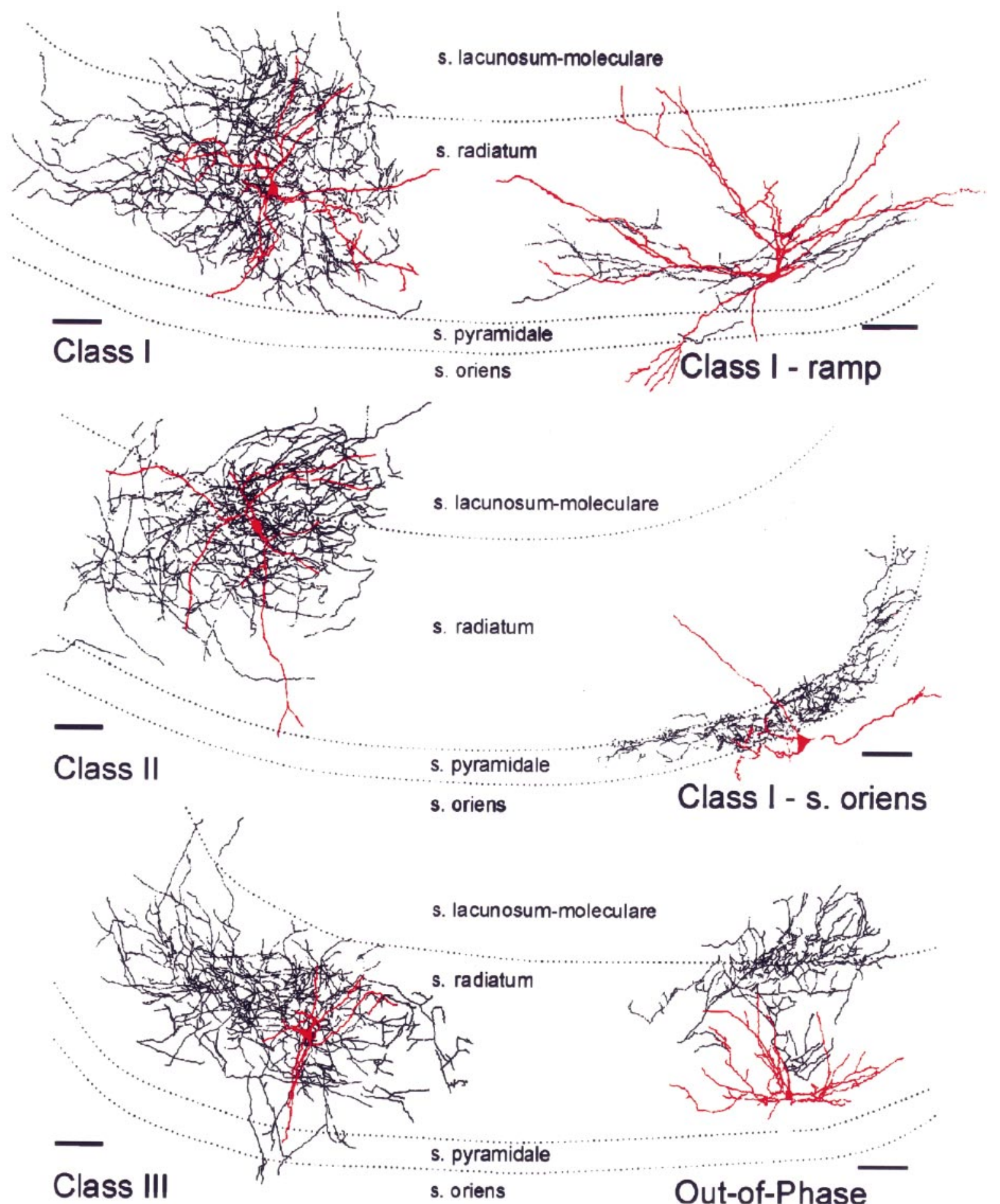

s. oriens

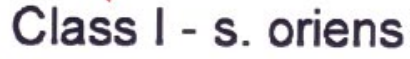

s. lacunosum-moleculare

s. radiatum

Figure 7. Camera lucida reconstructions of biocytin-filled interneurons. Top left, Example of a class I interneuron with electrical responses like those shown in Figure 2. Top right, Example of a class I interneuron that displays the ramp depolarization before each carbachol-induced oscillation (as illustrated in Fig. 3). Middle left, Camera lucida reconstruction of a biocytin-filled class II interneuron (like that in Fig. 4). Middle right, Camera lucida reconstruction of a neuron with cell body in st. oriens, with extensive axon ramification within st. pyramidale, where it is likely to inhibit pyramidal cell somata (like that in Fig. 6). Scale bars, $100 \mu \mathrm{m}$. Bottom left, Camera lucida reconstruction of a class III interneuron that had no synaptic events during carbachol oscillations (like that in Fig. 5). Bottom right, Single interneuron in the study that fired out of phase with the carbachol oscillations. The dendrites were thick and had many spines; axon was primarily in st. lacunosum-moleculare and st. radiatum, with one branch running into the granule and molecular layers of the dentate gyrus. 
pyramidal cells simultaneously. Class I interneurons may control burst duration, as they presumably inhibit pyramidal cells nearly synchronously with excitatory inputs. Even with $\mathrm{GABA}_{\mathrm{A}}$ receptors blocked, pyramidal cells are capable of firing in a bursting pattern, demonstrating that GABAergic interneurons promote but are not essential for burst initiation (Konopacki and Golebiewski, 1993; Lukatch and MacIver, 1997).

\section{Class I interneurons are excited during pyramidal cell bursts}

CA3 pyramidal cells are a likely major source of excitation for class I interneurons. A depolarizing $\mathrm{GABA}_{\mathrm{A}}$ conductance has been described in hippocampal interneurons (Perreault and Avoli, 1989; Michelson and Wong, 1991, 1994; Dickson and Alonso, 1997); if such a conductance links class I interneurons together, it may contribute to interneuron depolarization during the pyramidal cell burst. However, even when picrotoxin altered the pattern of pyramidal cell bursting, class I interneurons continued to follow pyramidal cell firing (our unpublished observations). This suggests that glutamatergic afferents rather than GABAergic afferents primarily drive rhythmic excitation of class I interneurons during carbachol oscillations. St. oriens interneurons fall within class I, based on their robust firing during each pyramidal cell burst.

\section{The pyramidal cell population can be silenced by firing in single interneurons}

Previous work suggested that interneurons with axons primarily innervating pyramidal cell bodies are most likely to control synchronous firing in pyramidal cells because the inhibition is delivered close to the site of action potential generation (Miles et al., 1996). Interneurons with axons localized primarily in st. radiatum have instead been proposed not to synchronously inhibit pyramidal cells but instead to control dendritic spike duration (Miles et al., 1996). Surprisingly, in two recorded class I interneurons a marked quieting of the pyramidal cell population was clearly observed during interneuron firing. Axon labeling was recovered for one that showed axon exclusively in st. radiatum in which it is most likely to innervate pyramidal cell dendrites. This result indicates that a single class I interneuron with st. radiatum axon can provide powerful inhibitory drive to the pyramidal population. Alternatively, we may have recorded from one of a group of class I interneurons that fire together to provide synchronous inhibitory drive to pyramidal cells (Michelson and Wong, 1991, 1994).

\section{Class II interneurons are inhibited by other interneurons}

Class II interneurons are only weakly depolarized by carbachol and are inhibited during the pyramidal cell burst. One likely source of the inhibitory input is the class I interneurons, which are excited during pyramidal cell bursts and may in turn release GABA onto their class II neighbors. Class II cells are also synaptically excited to some extent by pyramidal cells because when $\mathrm{GABA}_{\mathrm{A}}$ receptors were blocked, subthreshold EPSPs were unmasked. It is therefore possible that class I and class II interneurons represent a continuum along which class I cells are driven more strongly by excitatory afferents and more weakly by inhibitory afferents, whereas class II cells exhibit the opposite. Because class II interneurons were encountered rarely (3 of 42 interneurons), it is difficult to define them confidently; indeed, we cannot rule out that these cells represent class I interneurons selectively isolated from excitatory inputs during slicing.
During in vivo experiments, whereas most interneurons fire in phase with theta rhythm, a small number of interneurons in st. radiatum reduce their firing rate during theta activity ("theta-off cells") (Buzsaki and Eidelberg, 1983; Colom and Bland, 1987). Other st. radiatum interneurons in area CA1 are inhibited during sharp-wave "ripples" in vivo (Freund and Buzsaki, 1996). If these interneurons were encountered in vitro, they might well exhibit properties like those of class II interneurons, which reduce their excitability during pyramidal cell activity.

\section{Class III interneurons are only weakly innervated by CA3 pyramidal cells}

In contrast to class I interneurons, class III interneurons are excited only weakly or not at all during oscillations in the pyramidal cell population. Rhythmic IPSPs, seen in class II interneurons, were also not observed. Instead, class III interneurons may be driven exclusively by a population of neurons outside the hippocampus (for example, septal afferents responsible for theta rhythm), or perhaps by hippocampal afferents from other regions along the septotemporal axis. A rarely encountered group of interneurons in st. radiatum of area CA1 is also unaffected during sharp-wave related ripples recorded in vivo (Freund and Buzsaki, 1996). The class III interneurons we recorded from in area CA3 may be similarly synaptically connected.

We did observe a preponderance of class III interneurons in CA2 adjacent to area CA1. It may seem that excitatory inputs from CA3b (the pyramidal cell population responsible for the oscillations) to interneurons in CA2 might be severed in the slice, thus explaining the lack of synaptic input to class III cells. We think this unlikely, however, because the much more distant CA1 pyramidal cells are strongly excited during each carbachol oscillation (Williams and Kauer, 1997). Our data indicate that CA3b pyramidal neurons (and interneurons of CA3a and CA3b) do not innervate CA2 interneurons, although Schaffer collaterals pass through this region on their path to $\mathrm{CA} 1$, at least in the necessarily limited slice preparation.

\section{Functionally different interneurons have similar dendritic and axonal arbors}

Although we identified functionally distinct classes of interneurons in area CA3, the axons and dendrites of interneurons in all classes were indistinguishable. A similar homogeneity of CA3 interneuron morphology has been noted previously (McBain and Dingledine, 1993; Jaffe et al., 1997). The expression of calciumbinding proteins in hippocampal interneurons correlates with specific afferent inputs from both hippocampal and extrahippocampal regions (Sloviter and Nilaver, 1987; Freund and Antal, 1988; Toth and Freund, 1992; Freund and Buzsaki, 1996; Gulyas et al., 1996). It will be of interest to determine whether the three interneuron classes we have defined may be correlated with these groups.

\section{Interneurons may switch the local network from one rhythm to another}

Our description of functionally distinct interneuron classes illustrates that under one set of conditions in the network (general excitation by carbachol, rhythmic firing in CA3 pyramidal neurons), local interneurons do not all behave identically. Class I interneurons are most powerfully excited by local pyramidal cells, whereas class II interneurons are strongly inhibited by other local interneurons. Class III interneurons are relatively unaffected during carbachol oscillations and may represent a population of interneurons that "sit out" this particular hippocampal activity. 
The interneurons, by virtue of their powerful synchronizing capabilities and extensive axon arbors, represent logical candidates to switch the local network from one oscillatory state to another. We propose that just as the interneuron classes are differentially activated by local afferents, they may also be innervated differently by subcortical and cortical afferents. For example, serotonergic afferents from the raphe nuclei potently and selectively innervate calbindin-positive interneurons, which in turn inhibit local pyramidal cells (Freund et al., 1990). Although the function of this input is not well defined, serotonin afferents may regulate a form of theta rhythm in vivo, causing interneurons to fire rhythmically (Leung and Yim, 1986; Vanderwolf, 1988; Ylinen et al., 1995). Interneurons activated by serotonergic input may be identical with one of the three interneuron classes defined during carbachol oscillations. Another example of rhythmic activity can be produced in vitro in the presence of 4-aminopyridine. Hippocampal interneurons then excite one another directly via $\mathrm{GABA}_{\mathrm{A}}$ receptors, producing large synchronous IPSPs in the pyramidal cell population (Michelson and Wong, 1991). In vivo, interneurons linked in such a network have been postulated to synchronously activate pyramidal cells throughout the forebrain at gamma frequency $(40-100 \mathrm{~Hz})$, binding neural representations of concurrently perceived information (Bragin et al., 1995; Buzsaki and Chrobak, 1995; Whittington et al., 1995; Traub et al., 1996b). Again, one of the functionally defined interneuron classes may be responsible for this electrical activity.

In conclusion, the same neuronal wiring diagram can deliver very different output depending on which interneuron classes are active in a given situation. It will be of interest to record from the same interneuron populations during distinct network activities to test the idea that the classes of interneurons we have identified can switch the network from one state to another.

\section{REFERENCES}

Bal T, von Krosigk M, McCormick DA (1995) Synaptic and membrane mechanisms underlying synchronized oscillations in the ferret lateral geniculate nucleus in vitro. J Physiol (Lond) 483:641-663.

Bergles DE, Doze VA, Madison DV, Smith SJ (1996) Excitatory actions of norepinephrine on multiple classes of hippocampal CA1 interneurons. J Neurosci 16:572-585.

Bianchi R, Wong, RKS (1994) Carbachol-induced synchronized rhythmic bursts in CA3 in neurons of guinea pig hippocampus in vitro. J Neurophysiol 72:131-138.

Bland BH (1990) Physiology and pharmacology of hippocampal formation theta rhythms. Prog Neurobiol 26:1-54.

Bragin A, Jando G, Nadasdy Z, Hetke J, Wise K, Buzsaki, G (1995) Gamma (40-100 Hz) oscillation in the hippocampus of the behaving rat. J Neurosci 15:47-60.

Buhl EH, Halasy K, Somogyi P (1994) Diverse sources of hippocampal unitary inhibitory postsynaptic potentials and the number of synaptic release sites. Nature 368:823-828.

Buzsaki G, Chrobak JJ (1995) Temporal structure in spatially organized neuronal ensembles: a role for interneuronal networks. Curr Opin Neurobiol 5:504-510.

Buzsaki G, Eidelberg E (1983) Phase relations of hippocampal projection cells and interneurons to theta activity in the anesthetized rat. Brain Res 266:334-339.

Buzsaki G, Leung L, Vanderwolf CH (1983) Cellular bases of hippocampal EEG in the behaving rat. Brain Res Rev 6:139-171.

Cantrell AR, Ma JY, Scheuer T, Catterall, WA (1996) Muscarinic modulation of sodium current by activation of protein kinase $\mathrm{C}$ in rat hippocampal neurons. Neuron 16:1019-1026.

Cobb SR, Buhl EH, Halasy K, Paulsen O, Somogyi P (1995) Synchronization of neuronal activity in hippocampus by individual GABAergic interneurons. Nature 378:75-78.

Colom L, Bland B (1987) State-dependent spike train dynamics of hippocampal formation neurons: evidence for theta-on and theta-off cells. Brain Res 422:277-286.
Dickson CT, Alonso A (1997) Muscarinic induction of synchronous population activity in the entorhinal cortex. J Neurosci 17:6729-6744.

Frazier CJ, Rollins YD, Breese CR, Leonard S, Freedman R, Dunwiddie TV (1998) Acetylcholine activates an $\alpha$-bungarotoxin-sensitive nicotinic current in rat hippocampal interneurons, but not pyramidal cells. J Neurosci 18:1187-1195.

Freund TF, Antal M (1988) GABA-containing neurons in the septum control inhibitory interneurons in the hippocampus. Nature 336:170-173.

Freund TF, Buzsaki G (1996) Interneurons of the hippocampus. Hippocampus 6:347-470.

Freund TF, Gulyas AI, Acsady L, Gorcs T, Toth K (1990) Serotonergic control of the hippocampus via local inhibitory interneurons. Proc Natl Acad Sci USA 87:8501-8505.

Gulyas AI, Hajos N, Freund TF (1996) Interneurons containing calretinin are specialized to control other interneurons in the rat hippocampus. J Neurosci 16:3397-3411.

Huerta PT, Lisman JE (1993) Heightened synaptic plasticity of hippocampal CA1 neurons during a cholinergically induced rhythmic state. Nature 364:723-725.

Huerta PT, Lisman JE (1995) Bidirectional synaptic plasticity induced by a single burst during cholinergic theta oscillation in CA1 in vitro. Neuron 15:1053-1063.

Huerta PT, Lisman JE (1996) Low-frequency stimulation at the troughs of $\theta$-oscillation induces long-term depression of previously potentiated CA1 synapses. J Neurophysiol 75:877-884.

Jaffe D, Hubbard A, Chitwood R, Claiborne B (1997) Morphological and physiological characterization of hippocampal CA3 non-pyramidal neurons. Soc Neurosci Abstr 23:2007.

Jones S, Yakel J (1997) Functional nicotinic ACh receptors on interneurones in the rat hippocampus. J Physiol (Lond) 504:603-610.

Konopacki J, Golebiewski H (1993) Theta-like activity in hippocampal formation slices: cholinergic-GABAergic interaction. NeuroReport 4:963-966.

Konopacki J, MacIver MB, Bland BH, Roth SH (1987) Carbacholinduced EEG "theta" activity in hippocampal brain slices. Brain Res 405:196-198.

Lacaille J-C, Schwartzkroin PA (1988) Stratum lacunosum-moleculare interneurons of hippocampal CA1 region. II. Intrasomatic and intradendritic recordings of local circuit synaptic interactions. J Neurosci 8:1411-1424.

Leung LS, Yim CY (1986) Intracellular records of theta rhythm in hippocampal CA1 cells of the rat. Brain Res 367:323-327.

Lorente de No R (1934) Studies on the structure of the cerebral cortex. II. Continuation of the study of the Ammonic system. J Psychol Neurol 46:113-177.

Lukatch H, MacIver M (1997) Physiology, pharmacology and topography of cholinergic neocortical oscillations in vitro. J Neurophysiol 77:2427-2445.

Maccaferri G, McBain CJ (1995) Passive propagation of LTD to stratum oriens-alveus inhibitory neurons modulates the temporoammonic input to the hippocampal CA1 region. Neuron 15:137-145.

MacVicar BA, Tse FWY (1989) Local neuronal circuitry underlying cholinergic rhythmical slow activity in CA3 area of rat hippocampal slices. J Physiol (Lond) 417:197-212.

McBain CJ, DiChiara TJ, Kauer JA (1994) Activation of metabotropic glutamate receptors differentially affects two classes of hippocampal interneurons and potentiates excitatory synaptic transmission. J Neurosci 14:4433-4445.

McBain CJ, Dingledine R (1993) Heterogeneity of synaptic glutamate receptors on $\mathrm{CA} 3$ st. radiatum interneurones of rat hippocampus. J Physiol (Lond) 462:373-392.

McMahon LL, Kauer JA (1997a) Hippocampal interneurons are excited by serotonin-gated ion channels. J Neurophysiol 78:2493-2502.

McMahon LL, Kauer JA (1997b) Hippocampal interneurons express a novel form of synaptic plasticity. Neuron 18:295-305.

McQuiston A, Madison D (1997) Diverse nicotinic responses in heterogeneous interneurons of area CA1 in the rat hippocampus. Soc Neurosci Abstr 23:2009.

Michelson HB, Wong RKS (1991) Excitatory synaptic responses mediated by $\mathrm{GABA}_{\mathrm{A}}$ receptors in the hippocampus. Science 253:1420-1423.

Michelson HB, Wong RKS (1994) Synchronization of inhibitory neurones in the guinea-pig hippocampus in vitro. J Physiol (Lond) 477:35-45.

Miles R, Toth K, Gulyas AI, Hajos N, Freund TF (1996) Differences between somatic and dendritic inhibition in the hippocampus. Neuron $16: 815-823$. 
Mody I, Staley KJ (1994) Cell properties in the epileptic hippocampus. Hippocampus 4:275-280.

Perreault P, Avoli M (1989) Effects of low concentrations of 4-aminopyridine on CA1 pyramidal cells of hippocampus. J Neurophysiol 61:953-970.

Sah P, Hestrin S, Nicoll RA (1990) Properties of excitatory postsynaptic currents recorded in vitro from rat hippocampal interneurons. J Physiol (Lond) 430:605-616.

Sloviter RS, Nilaver G (1987) Immunocytochemical localization of GABA-, cholecystokinin-, vasoactive intestinal polypeptide-, and somatostatin-like immunoreactivity in the area dentata and hippocampus of the rat. J Comp Neurol 256:42-60.

Soriano E, Frotscher M (1993) Spiny nonpyramidal neurons in the CA3 region of the rat hippocampus are glutamate-like immunoreactive and receive convergent mossy fiber input. J Comp Neurol 332:435-448.

Spruston N, Lubke J, Frotscher M (1997) Interneurons in the stratum lucidum of the rat hippocampus: an anatomical and electrophysiological characterization. J Comp Neurol 385:427-440.

Toth K, Freund TF (1992) Calbindin D28k-containing nonpyramidal cells in the rat hippocampus: their immunoreactivity for GABA and projection to the medial septum. Neuroscience 49:793-805.

Toth K, Freund TF, Miles R (1997) Disinhibition of rat hippocampal pyramidal cells by GABAergic afferents from the septum. J Physiol (Lond) 500:263-274.
Traub RD, Jefferys JGR (1994) Simulations of epileptiform activity in the hippocampal CA3 region in vitro. Hippocampus 4:281-285.

Traub RD, Miles R (1991) Neuronal networks of the hippocampus. Cambridge: Cambridge UP.

Traub RD, Miles R, Buzsaki G (1992) Computer simulation of carbachol-driven rhythmic population oscillations in the CA3 region of the in vitro rat hippocampus. J Physiol (Lond) 451:653-672.

Traub RD, Borck C, Colling SB, Jefferys JGR (1996a) On the structure of ictal events in vitro. Epilepsia 37:879-891.

Traub RD, Whittington MA, Stanford IM, Jefferys JGR (1996b) A mechanism for generation of long-range synchronous fast oscillations in the cortex. Nature 383:621-624.

Vanderwolf CH (1988) Cerebral activity and behavior: control by central cholinergic and serotonergic systems. Int Rev Neurobiol 30:225-340.

Whittington MA, Traub RD, Jefferys JGR (1995) Synchronized oscillations in interneuron networks driven by metabotropic glutamate receptor activation. Nature 373:612-615.

Williams JH, Kauer JA (1997) Properties of carbachol-induced oscillatory activity in rat hippocampus. J Neurophysiol 78:2631-2640.

Ylinen A, Soltesz I, Bragin A, Penttonen M, Sik A, Buzsaki G (1995) Intracellular correlates of hippocampal theta rhythm in identified pyramidal cells, granule cells, and basket cells. Hippocampus 5:78-90. 